\title{
PROPRIEDADES DE TRAÇÃO EM COMPÓSITOS DE MATRIZ EPOXI REFORÇADAS COM FIBRAS ALINHADAS DE MALVA, SISAL E BAMBU*
}

\section{Resumo}

\author{
Jean Igor Margem ${ }^{1}$ \\ Carolina Gomes Dias Ribeiro ${ }^{2}$ \\ Marina Rangel Margem ${ }^{3}$ \\ Ygor Macabu de Moraes ${ }^{4}$ \\ Frederico Muylaert Margem ${ }^{5}$ \\ Sergio Neves Monteiro ${ }^{6}$
}

Nestes dias materiais ecológicos como compósitos com fibras naturais em matriz polimérica estão chamando a atenção de pesquisadores científicos, devido ao seu bom desempenho na substituição de materiais como madeira, polímeros à base de petróleo e outros. Neste trabalho foram avaliadas as propriedades de tração de compósitos de matriz epóxi reforçados com diferentes espécimes de fibras lignocelulósicas. Compósitos reforçados com até 30\% em volume de fibras longas, contínuas e alinhadas de malva, sisal e bambu foram testados em uma máquina Instron a temperatura ambiente. A fratura foi analisada por SEM. Os resultados mostraram alterações significativas nas propriedades mecânicas com a quantidade dessas fibras. Estas propriedades mecânicas foram comparados com outros resultados em compósitos testados em ensaio de tração. A análise da fratura revelou uma fraca interação da interface fibra / matriz, o que poderia ser responsável por um maior desempenho de algumas propriedades.

Palavras-chave: Fibras de malva; Sisal; Bambu; Matriz Epoxi; Ensaio tração.

\section{TENSILE PROPERTIES OF EPOXY COMPOSITES REINFORCED WITH CONTINUOUS MALVA, SISAL AND BAMBOO FIBERS}

\begin{abstract}
In these days environmentally friendly materials as composites with natural fibers in polymeric matrix are gained attention of scientific researchers, due to its good performance in the replacement of materials such as wood, petroleum-based polymers and other. In this work the tensile properties of DGEBA/TETA epoxy matrix composites reinforced with different specimens of lignocellulosic fibers were evaluated. Composites reinforced with up to $30 \%$ in volume of long, continuous and aligned malva, sisal, and bamboo fibers were room temperature tested in an Instron machine. The fracture was analyzed by SEM. The results showed significant changes in the mechanical properties with the amount of those fibers. These mechanical properties were compared with other tensile-tested composites results. The fracture analysis revealed a weak fiber/matrix interface, which could be responsible for the higher performance of some properties.
\end{abstract}

Keywords: Malva; Sisal; Bamboo fibers; Epoxy matrix; Tensile strength tests.

1 Doctor In Materials Engineering, Associate Professor, Department of Mechanical Engineering, ISECENSA, Campos dos Goytacazes, Rio de Janeiro, Brasil.

2 Graduating In Metallurgical Engineering And Materials, Student, Department of Materials, State University of the Northen Rio de Janeiro, Campos dos Goytacazes, Rio de Janeiro, Brasil.

3 Graduated In Chemical Engineering, Department of Chemical Engineering, Federal University of the Rio de Janeiro, Rio de Janeiro, Brasil.

4 Graduating In Metallurgical Engineering And Materials, Student, Department of Materials, State University of the Northen Rio de Janeiro, Campos dos Goytacazes, Rio de Janeiro, Brasil.

5 Doctor In Materials Engineering, Associate Professor, Department of Electrical Engineering, Faculdade Redentor, Itaperuna, Rio de Janeiro, Brasil.

6 Phd In Materials Engineering, Emeritus Professor, Department of Materials, IME, Rio de Janeiro, Rio de Janeiro, Brazil. 


\section{INTRODUCTION}

In recent years polymer composites reinforced with natural fibers, mainly those lignocellulosic obtained from plants, have been subject to extensive research works ${ }^{1-}$ 5. Environmental, economical, societal and technical advantages of these composites are motivating their substitution for similar polymer composites reinforced with synthetic fibers. In particular, R\&D efforts have been conducted aiming to replace glass fibers composites that are comparatively more abrasive to equipments, nonrecyclable, more expensive, heavier and toxic ${ }^{6}$.

Among the many lignocellulosic fiber composites being investigated, those fabricated with sisal leaf defibrillated fiber, malva stripped pseudo stem and bamboo fibers longitudinally cut from the culm, still need information to support possible industrial applications. Several works, however, have been dedicated to those fibers as possible reinforcement of polymer composites ${ }^{7-17}$. These works reported mechanical properties that could markedly vary with the type of polymer matrix, the fiber disposition (if continuous, aligned, short-cut, mat interlayered, etc) and the test condition.

In a recent work ${ }^{18-20}$, it was found that the tensile strength of malva, sisal and bamboo fibers varies inversely with their corresponding diameters. In other words, the thinner the diameter, the stronger the fiber. This indicates that these fibers have a potential to be applied as composite reinforcement. Nevertheless, limited amount of tensile data has so far been reported on malva, sisal and bamboo fibers reinforced polymer composites. Therefore, the objective of this paper was to assess and compare the tensile properties and mechanical characteristics of epoxy composites reinforced with thinner and continuous malva, sisal, and bamboo stripped fibers.

The malva fibers obtained from the stem of the malva plants (Urena Lobbata, Linn), Fig. 1a, are among the strongest lignocellulosic with tensile strength above 450 $\mathrm{MPa}^{29}$. Another particular case is the sisal fiber, the plant can be seen in Figure $1 \mathrm{~b}$, which fibers are stripped from the leave of the plant (Agave sisalana) and their tensile strength can achieve around $730 \mathrm{MPa}^{22}$, to complete the analysis the bamboo plant have it fibers extracted from the stem of the plant as can be seen in Figure 1c, the (Dendrocalamus giganteus) from the Brazil, is a plant with great potential for the use of its lignocellulosic fibers and its tensile strength can achieve around $440 \mathrm{MPa}^{23}$.
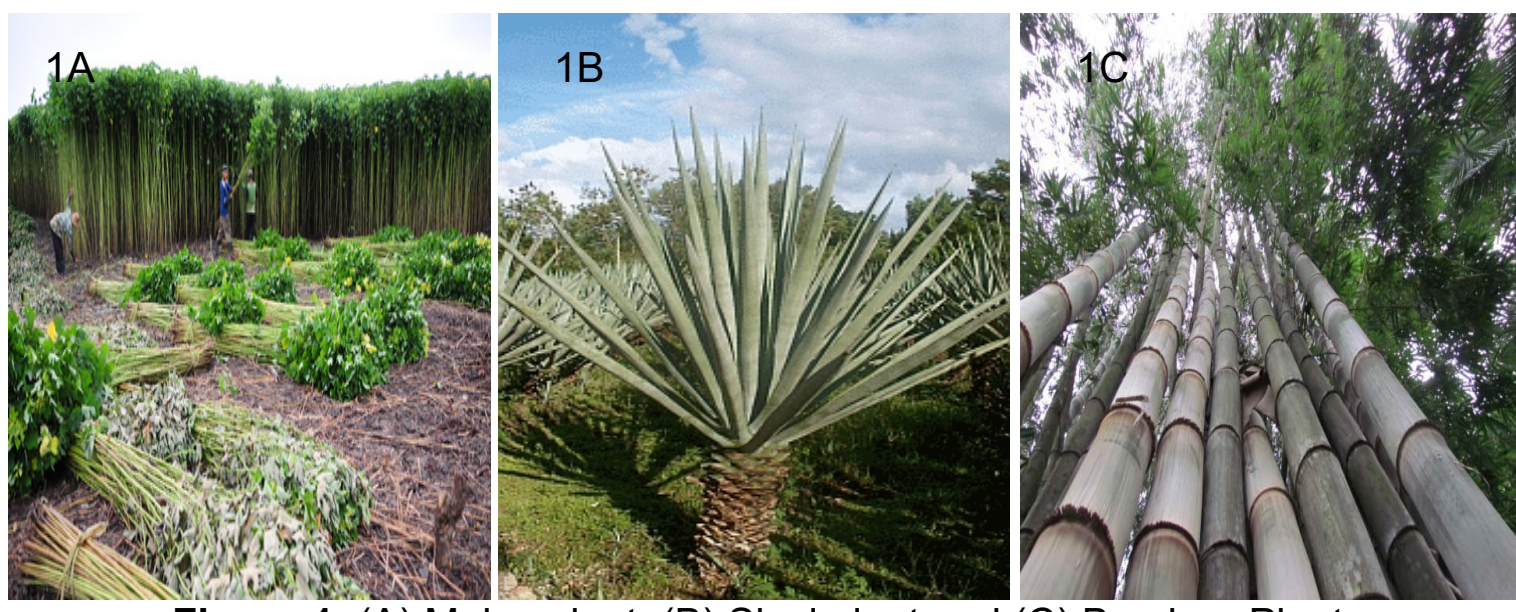

Figure 1. (A) Malva plant, (B) Sisal plant and (C) Bamboo Plant.

In spite of existing works on the properties of those fibers composites separated $21-23$, the Tensile resistance comparison of thinner, continuous and aligned malva, sisal, and bamboo 
fibers reinforced polymeric composites has yet to be evaluated. Therefore, the objective of the present work was to access the tensile resistance through test specimens of epoxy composites reinforced with different amounts of aligned and continuous malva, sisal and bamboo fibers.

\section{MATERIAL AND METHODS}

A $3 \mathrm{~kg}$ lot of sisal fibers were donated by the Sisalsul fibers, a local fiber producer, a long culm of bamboo and a malva were donated by Companhia Textil Castanhal from Pará, North region of Brazil ${ }^{30}$. The malva and sisal fibers from the as received lot were cleaned and dried at room temperature, figure $2 \mathrm{~A}$ and $2 \mathrm{~B}$, the sundried culm of bamboo was stripped with a razor blade, figure $2 \mathrm{C}$.
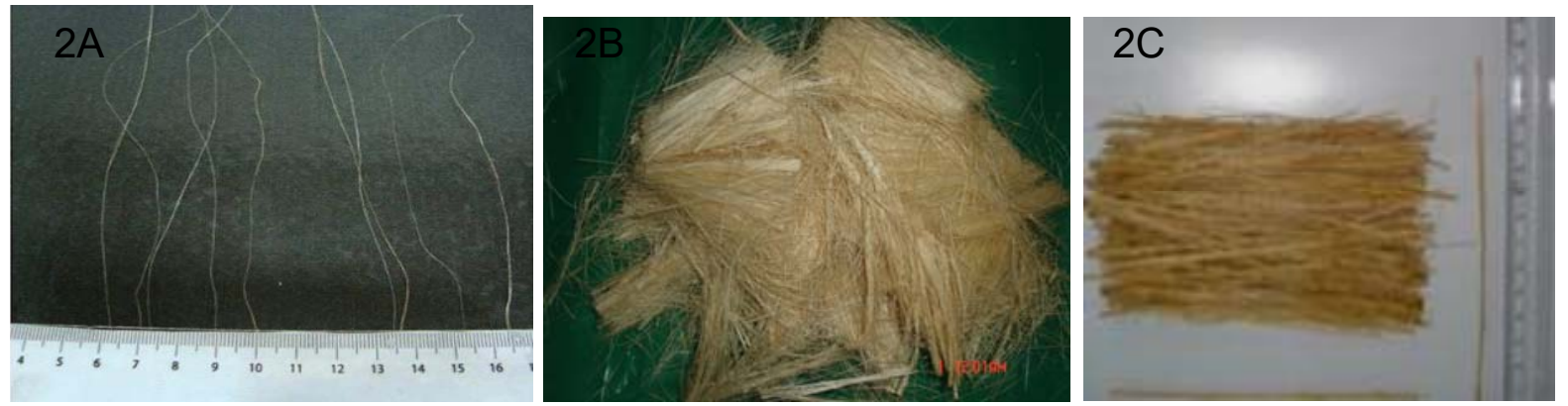

Figure 2. (A) Malva fiber, (B)Sisal fiber and (C) Bamboo fiber.

After separation, cleaning and drying at room temperature, the fibers were mixed in amounts of $0,10,20$ and $30 \%$ in volume with epoxy resin type diglycidyl ether of the bisphenol-A (DGEBA) with a DER of $374 \mathrm{~g} / \mathrm{mol}$ and an equivalent weight of 187.3g/equiv. with triethylene tetramine (THETA), as hardener, in stoichiometric ratio corresponding to phr 13 . Both DGEBA resin and THETA hardener were supplied by the DOW Chemical Co.

The fibers were maintained aligned along the length dimension in the dog bone shape composites. The still fluid mixture was poured onto the fibers inside a steel mold and allowed to cure at room temperature (RT) for 24 hours. Seven specimens were prepared for each volume fraction and each fiber kind.

The specimens were tested at RT in a model DL 10000 Instron machine at a strain rate of $3 \times 10^{-3} \mathrm{~s}^{-1}$. After test, representative fractured samples were placed in a conducting support and then gold-coated to be analyzed by scanning electron microscopy (SEM). This analysis was conducted in a model SSX-550 Shimadzu microscope operating with secondary electrons accelerated by a voltage of $15 \mathrm{kV}$.

\section{RESULTS AND DISCUSSION}

Table I shows the results of the values of charpy impact energy with their respective standard deviations for pure epoxy and composites with different volume fractions of sisal, bamboo and malva fibers. 
Table I - Tensile resistance for composites with sisal, bamboo and malva fibers.

\begin{tabular}{|c|c|c|c|}
\hline $\begin{array}{c}\text { Fiber } \\
\text { Percentage } \\
(\%)\end{array}$ & $\begin{array}{c}\text { Sisal Tensile } \\
\text { Strength (MPa) }\end{array}$ & $\begin{array}{c}\text { Bamboo Tensile } \\
\text { Strength (MPa) }\end{array}$ & $\begin{array}{c}\text { Malva Tensile } \\
\text { Strength (MPa) }\end{array}$ \\
\hline 0 & $32.76 \pm 2.09$ & $34.44 \pm 2.50$ & $32.99 \pm 1.58$ \\
\hline 10 & $69.09 \pm 5.06$ & $80.24 \pm 8.27$ & $73.75 \pm 9.01$ \\
\hline 20 & $118.42 \pm 9.99$ & $96.99 \pm 8.72$ & $95.98 \pm 7.81$ \\
\hline 30 & $142.86 \pm 11.73$ & $133.39 \pm 10.98$ & $130.98 \pm 1.71$ \\
\hline
\end{tabular}

Based on the results of Table I, the Tensile stress variation as a function of the amount of the different fibers is shown in Figure 3.

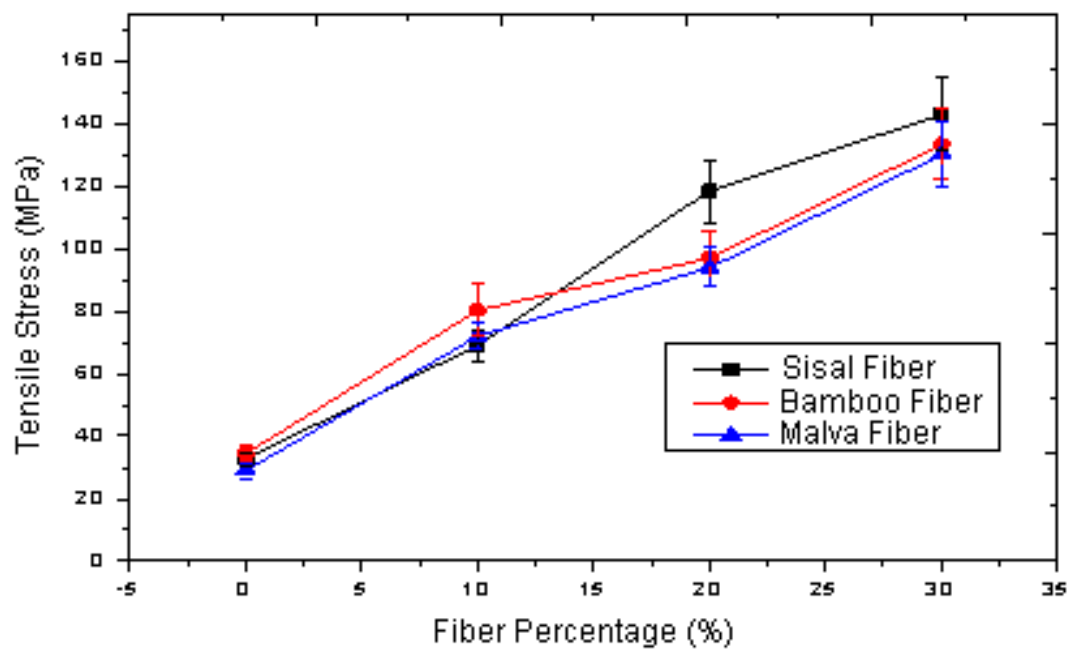

Figure 3. Tensile stress as a function of the amount of the different fibers.

One should notice the marked increase in tensile stress with the fiber volume fraction of all kind. It is also important to note that the error bars present the standard deviation, a common feature for lignocellulosic fibers. This is due to the heterogeneous nature of natural fibers, resulting in substantial dispersion properties of the composites reinforced by them ${ }^{24}$. The comparison show that the bamboo fiber generates a better reinforcement to epoxy composites when incorporated with $10 \%$ in volume of fiber but it is not true to 20 and $30 \%$ in volume. After $20 \%$ incorporation the sisal fiber shows a better reinforcement, probably because its smaller diameter, what assure less pores and hole in the fiber structure and a more uniform behavior.

It is important to discuss the macroscopic rupture characteristic of the specimens after the test. It is important to observe that some specimens with $30 \%$ of malva fiber, some with 20 and $30 \%$ of curaua fiber and some with 10, 20 and $30 \%$ of ramie fiber did not complete brake, ie the highest toughness obtained, do not separated into two parts after impact as showed in other work in literature ${ }^{25}$. This indicates that cracks nucleated in the notch began to propagate across the brittle epoxy matrix, but when they reach the fiber interface, the crack changes direction.

All specimens under $20 \%$ bamboo and malva fiber incorporation and under $10 \%$ sisal fiber incorporation, undergo complete rupture. Some specimens with $20 \%$ and $30 \%$ incorporation of sisal fiber and some with $30 \%$ incorporation of malva and bamboo fibers did not undergo complete rupture. This leads to a decrease in tensile tested for 
these specimens. If the specimens complete brake, the tensile stress would have been even greater ${ }^{26}$.

A possible explanation for the reinforcement effect of the Malva, Sisal and bamboo fibers to the epoxy matrix, Table I and Fig. 3, may be understood through the fracture analysis of the composites presented in Fig. 4 and 5.

Details of the typical tensile specimens fracture corresponding to $0 \%$ (pure epoxy) with lower magnification in Fig. 4A shows a single crack propagated in a longitudinal way, and with higher magnification, showing the details, in Fig.4B, it can be observed the propagation of many cracks through an irregular epoxy matrix, with pores and defects accumulated during the processing of the tensile specimens.
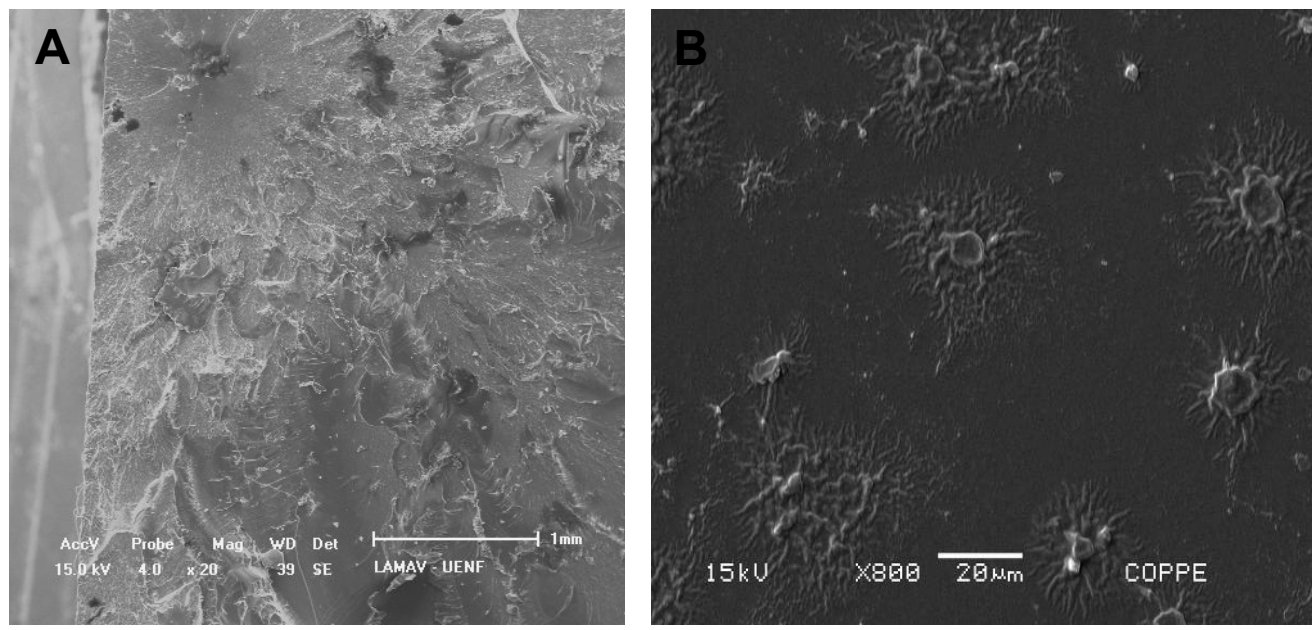

Figure 4. Fracture surface of the pure epoxy specimen (0\% fiber): $(A)$ general view with low increase (B) higher increase.

Figures 5 presents details of the tensile stress surface of epoxy composite specimens with $30 \%$ of sisal, bamboo and malva fiber. This fractograph shows an effective adhesion between the fibers and matrix, where cracks preferentially propagate. Some of the fibers were pulled out from the matrix and others were broken during the impact ${ }^{25,26}$. By contrast, the part of the specimen in which the rupture preferentially occurred longitudinally through the fiber/matrix interface reveal that most of the fracture area is associated with the fiber surface. This behavior corroborates the rupture mechanism of cracks that propagate preferentially in between the fiber surface and the epoxy matrix due to the low interfacial strength ${ }^{27}$. The greater fracture area, Fig. 5, associated with the aligned fibers acting as reinforcement for the composite, justify the higher absorbed impact energy, Fig. 3 with increasing amount of the lignocellulosic fibers.

This behavior confirms the mechanism of rupture by cracks that due to the low interfacial shear stress, is preferably spread between the surface of the sisal, bamboo and malva fibers and the epoxy matrix as can be seen in Figure 5A, 5B and $5 \mathrm{C}^{28}$.

This result in a longitudinal fracture area is relatively large compared to the transverse fracture of the specimens with up to $20 \%$ of bamboo and malva fiber and up to $10 \%$ of sisal. Consequently have a higher tensile stress to break an area comparatively higher as indicated by Yue ET AL (1995). This indicates that the fibers provide a high tensile resistance to polymeric matrices when used as composites reinforcement. 

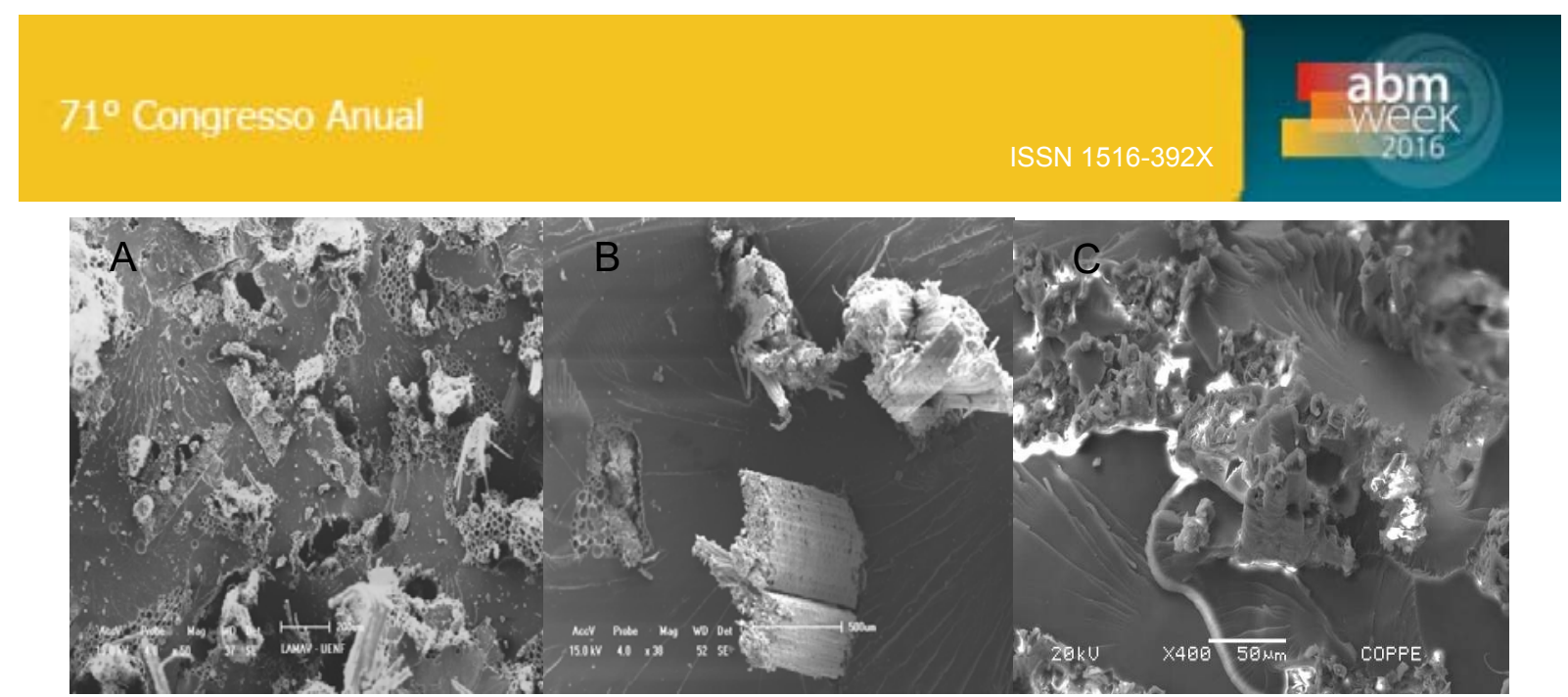

Figure 5. Fracture surface of the specimen with $30 \%(A)$ sisal, $(B)$ bamboo and $(C)$ malva fiber/epoxy composite general view with higher increase.

\section{CONCLUSIONS}

Malva, Sisal and Bamboo fiber fractions increased in a linear way the tensile stress absorbed during the bend test due to the energy required test the composites. The bamboo fiber generates a better reinforcement to epoxy composites when incorporated with up to $10 \%$ in volume, but it is not true to 20 and $30 \%$ incorporation. After $20 \%$ incorporation the Sisal fiber shows a better reinforcement, probably because its smaller diameter, what assure less pores and hole in the fiber structure and a more uniform behavior. This increase the tensile stress is apparently due to the low shear stress at the interface between the Malva, Sisal, Bamboo and fibers and epoxy matrix. This result in a high energy absorbed as a result of propagation of longitudinal cracks through the interface, which generates a fracture area is relatively large compared to the simple transverse fracture.

\section{Acknowledgments}

The authors thank the support to this investigation by the Brazilian agencies: CNPQ, CAPES, FAPERJ and TECNORTE/FERNORTE.

\section{REFERENCES}

1 A.K. Bledski and J. Gassan: Composites reinforced with cellulose-based fibers. Prog. Polym. Sci, Vol.4 p.221-274 (1999).

2 A.K. Mohanty, M. Misra and G. Hinrichsen: Biofiber, biodegradable polymers and biocomposites: an overview. Macromol. Mat. Eng. Vol. 276/277 p.1-24 (2000).

3 D. Nabi Sahed and J.P. Jong: Natural fiber polymer composites: a revew. Adv. Polym. Technol. Vol. 18(4), p.351-363 (1999).

4 S.J. Eichhorn, C.A. Baillie, N. Zafeiropoulos, L. Y. Mwaikambo, M.P. Ansell and A. Dufresne: Review - Current international research into cellulosic fibers and composites. J. Mat. Sci. Vol. 36 p. 19-26 (2002).

5 A.K. Mohanty, M. Misra and L.T. Drzal: Sustainable bio-composites from renewable resources: opportunities and challenges in the green materials world. J Polym Environ Vol. 10 p. 19-26 (2002).

6 A.N. Netravali and S. Chabba: composites get greener. Mater Today. Vol. 6 p.22-29 (2003).

7 J. Crocker: Natural materials innovative natural composites. Mater Technol Vol. 2-3; $p$. 174-178 (2008).

8 M.J. John and S. Thomas: Biofibers and biocomposites. Carbohydr. Polym. Vol. 71; p.343-364 (2008). 
9 Kestur G. Satyanarayana, Gregorio G. C. Arizaga, and Fernando Wypych.

Biodegradable composites based on lignocellulosic fibers - An overview. Progress in Polymer Sience. Vol. 34 p. 982-1021 (2009).

10 S.N. Monteiro, F.P.D. Lopes, A.S. Ferreira and D.C.O. Nascimento: Natural fiber polymer matrix composites: cheaper, tougher and environmentally friendly. JOM. Vol. 61 p. 17-22 (2009).

11 S.N. Monteiro, F.P.D. Lopes, A.P. Barbosa, A. B. Bevitori, I.L. Silva and L.L. Costa: Natural Lignocellulosic fibers as engineering materials. Metal. Mater. Trans A, Vol. 42 p. 2963-2974, (2011).

12 S. Kalia, B.S. Kaith and I. Kaurs: Cellulose Fibers: Bio and Nano-Polymer Composites . (New York: Springer, (2011).

13 O. Faruk, A.K. Bledski, H.P. Fink and M. Sain: Biocomposites reinforced with natural fibers: 2000-2010. Progress in Polymer Science. Vol.37 p.1552-1596 (2012).

14 K. G. Satyanarayana; J. L. Guimarães; F Wypych. Studies on lignocellulosic fibers of Brazil. Part I: Source, production, morphology, properties and applications. Composites: Part A, v. 38, p. 1694-1709, (2007).

15 A; Gore An Inconvenient Truth, Uma Verdade Incoveniente, Documentário e Livro, Editora Manole, New York, 328p, (2008).

16 S. P. Campanha Filho, E. Frollini, A. A. S, Curvelo, Organosolo Delignification of Ligonocellulose Materials: Preparation and Characterization of Lignin and Celulose Derivates, São Carlos: Inst de Quim -USP, (1997).

17 K. K. Chawla, Composite Materials Science and Engineering, New York: SpringerVerlag, (1987).

18 A.K.; Bledzki, J, Gassan. Composites reinforced with cellulose-based fibres. Prog. Polym. Sci, v. 24, p. 221-274, (1999).

19 D, Nabi Sahed; J.P.JOG Natural fiber polymer composites: a review, Advances in Polymer Technol., v.18, p. 221-274, (1999).

20 A.K. Mohanty, M Misra, G. Hinrichsen, Biofibres, biodegradable polymers and biocomposites: An overview. Macromolecular Mater. and Eng., v. 276, p.1-24, 2000.

21 J. Crocker, Natural materials innovative natural composites. Materials technology, v.2-3 n. 3 p. $174-178,(2008)$.

22 S. N. Monteiro.; F.P.D.Lopes, A.S.; Ferreira, D.C.O, Nascimento. Natural fiber polymer matrix composites: cheaper, tougher and environmentally friendly. JOM, v.61, n. 1, p. 17-22, (2009).

23 S.Y. Fu, B. Lauke, E. Mäder, X. Hu and C.Y. Yue, "Fracture resistance of short-glassfiber-reinforced and short-carbon-fiber-reinforced poly-propylene under charpy impact load and dependence on processing", J. Mater. Process. Technol., v.89-90, p.501-507, (1999).

24 S. N. Monteiro, R.C.M.P. Aquino, F.P.D. Lopes, Tenacidade ao entalhe por impacto charpy de compósitos de poliéster reforçados com fibras de piaçava. Rev. Mater., v.11, p.204-210, (2006).

25 S.N. Monteiro, W.P. Inácio, F.P.D. Lopes, Charpy toughness behavior of continuous sisal fiber reinforced polyester matrix composites, In: Mineral, Metals \& Materials Characterization symposium - TMS conference, Seattle, EUA, march, P 1-8, (2010).

26 C.Y. Yue, H.C. Looi, M. Y. Quek, Assessment of Fibre-Matrix Adhesion and Interfacial Properties Using the Pullout Test. Int. J. Adhesion and Adhesives, v. 15, p. 73-80, (1995).

27 S. N. Monteiro, L.L. Costa, F.P.D. Lopes, Characterization of the impact resistance of coir fiber reinforced polyester composites, In: Mineral, Metals \& Materials Characterization Symposium - TMS Conference, New Orleans, LA, USA, Março, , p. 1$6,(2008)$.

28 S. N. Monteiro, D.C.O, Nascimento, L.C. Motta; Characterization of the toughness of piassava fiber reinforced epoxy matrix by izod impact test. In: EPD Congress:

Characterization of Minerals, Metals and Materials - TMS Conference 2009, 2009, San 
Francisco (CA) USA. Proceedings of the EPD Congress: Characterization of Minerals, Metals and Materials - TMS Conference (2009).

29 J.I. Margem, S.N. Monteriro, M. Margem, V. Gomes, F. Margem; Pullout Tests of Epoxy Matrix Reinforced with Malva Fibers, In: EPD Congress: Characterization of Minerals, Metals and Materials - TMS Conference, Orlando, Florida, USA, March, p.457-463, (2015).

30 J.I. Margem, S.N. Monteriro, M. Margem, R.F. Junior, V. Gomes, T. Cordeiro, F. Margem; Photoacoustic Thermal Characterization of Malva Fibers, In: EPD Congress: Characterization of Minerals, Metals and Materials - TMS Conference, Orlando, Florida, USA, March, p.259-264, (2015). 